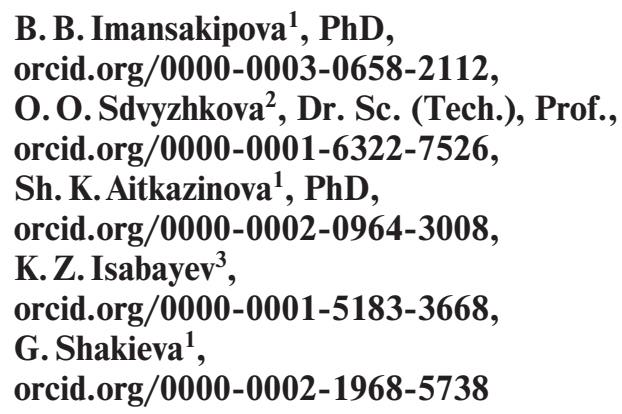

1 - Satbayev University, Almaty, the Republic of Kazakhstan, e-mail: imansakipova@mail.ru

2 - Dnipro University of Technology, Dnipro, Ukraine, e-mail: sdvyzhkova@gmail.com

3 - Military Engineering Institute of Radio Electronics and Communications, Almaty, the Republic of Kazakhstan

\title{
THE COMBINED METHOD FOR ASSESSING RISK FACTORS IN UNDERGROUND CONSTRUCTION
}

Purpose. Development of a combined method for qualitative and quantitative assessment of risk factors accompanying the construction and operation of underground constructions based on expert analysis and mathematical modeling by numerical methods.

Methodology. When creating a comprehensive method for ranking the underground construction route by the degree of problems, we used methods of expert assessment, statistical analysis and mathematical modeling, which allow us to assess the state of each section by summing the points of risk factors assessment.

Findings. Based on the results of practical application of the developed method for ranking the Almaty metro route sections by the degree of problems, the method has shown its effectiveness in solving the problems of ensuring the safety of construction and operation of the metro and has been adopted for implementation.

Originality. Assessment of the condition of the underground construction route section according to the degree of problematicity in accordance with the principle of adding risk factors through conditional points established by the results of expert analysis and mathematical modeling.

Practical value. The method improves the effectiveness of monitoring the state of the underground construction route, improves the quality of situational control as well as the forecast of the manifestation of risk situations and their development. The method can be used for solving similar problems in underground construction of different objects, including the development of mineral deposits.

Keywords: underground development, metro, risk factors, quartile, finite element method, stress distribution

Introduction. To improve the effectiveness of monitoring the state of the metro route, it is proposed to rank sections of the route by the degree of problems based on the qualitative and quantitative assessment of risk factors, and their levels using a method combining expert analysis and mathematical modeling of possible manifestations of risk situations. The model is created corresponding as much as possible to the actual occurrence of each section, including the geological structure, physical-mechanical properties of the enclosing massif, structure, elastic and strength characteristics of the concrete lining of the tunnel. This allows increasing the efficiency, reliability and, most importantly, the objectivity of risk factors assessment. The analysis of the metro section's problems is based on the following principles: addition of risk factors through conditional points assigned by experts; individuality - the most significant risk factors are established individually for each metro; section ranking by the degree of difficulty is carried out according to the quartile criterion, with three risk levels: low, medium, and high. The ranking is carried according to the criterion determined by the sum of the points of the risk factors of the site. As a result, the quality of situational control and forecasting risk situations is improved.

Problem statement. The use of underground transport allows us to unload ground highways, increases the speed and quality of movement around the city, reduces emissions and noise impact. At the same time, underground construction in cities is associated with certain difficulties: dense construction, saturation of communications, active traffic. In some cases, complex mining and geological conditions are added, as well as manifestations of geological processes, including seismic ones [1]. This is due to the fact that underground construction

(C) Imansakipova B. B., Sdvyzhkova O. O., Aitkazinova Sh. K., Isabayev K.Z., Shakieva G., 2020 is accompanied by progressive discontinuities and structural changes in the rock mass properties, activation of existing and manifestation of new geomechanical processes against the background of a reaction change in its stress-strain state. These processes complicate the situation, creating a threat to the safe conduct of mining operations and the operation of ground and underground structures located in the zone of mutual influence, provoking the creation of risky situations. In work [2], a complex natural and technical geosystem "geourbanistics-geological environment" was identified to open up the possibility of implementing a system methodology for developing underground space, increasing the volume and optimizing the risks of underground construction.

The method of morphological analysis was used to objectively justify the future development of underground megacities [3]. Analysis of the current state of the problem of ensuring the safety of construction and operation of the metro shows that it is necessary to create a comprehensive monitoring system for its successful solution, which accompanies underground construction both on the surface and inside the rock mass on the basis of modern technologies and methods [4]. However, considering the length of the metro route, to improve the effectiveness of monitoring, it is necessary to establish potentially dangerous sections of the likely manifestation of risk situations before it begins [5]. In this regard, improving the existing methods and developing new ones for assessing risk factors and their level of metro sections is of great scientific and practical interest.

Methods. When creating a comprehensive method for ranking the metro route according to the degree of problems, we used methods of expert assessment, statistical analysis and mathematical modeling, which allow us to assess the state of each section through the summation of risk factor assessment points [6]. 
Critical analysis. Currently, there are various methods for determining risk factors [3].

An example of solving similar monitoring tasks is underground mining of mineral deposits, construction and operation of oil trunk pipelines. The task is successfully solved by methods of expert assessment of risk factors and their levels [7].

The experts' opinion is significantly influenced by the completeness of the object's state data provided for analysis. In the work [8], based on expert assessments, the decision-making process on the feasibility of using the territory (geological environment) for urban underground construction in Kyiv is formalized. The authors analyzed the tools for evaluating the construction sites of underground facilities, justified the assessment of alternative states and the scale of expert assessments, and constructed matrices of relationships between factors of influence and parameters.

In [9], the possibilities of morphological analysis for assessing the suitability of urban areas for metro development are revealed. The use of this method allowed us to offer a number of solutions for underground construction on individual sites, taking into account the identified groups of geological and technogenic factors, uncertainties of various nature and groups of risk factors. It should be noted, however, that the cited works do not provide theoretical prerequisites for the compilation of morphological tables. For expert evaluation, it would be important to quantify the influence of a given factor by physical or mathematical modeling of the object's state.

The expert method (or expert evaluation method) is carried out by processing the opinions of experienced specialists and employees in this industry, from which an expert Commission is formed. Each expert is provided with a list of possible risks and is asked to assess the probability of their occurrence.

Naturally, experts' opinions on the degree of risk may differ greatly due to subjectivity. This circumstance is indicated by the author of the work [10] paying attention even to such personal characteristics as pessimism and optimism. Therefore, special attention should be paid to the selection of experts, since the correctness and impartiality of their assessments depends on the correctness of decision-making.

Thus, despite the success of the practical application of expert methods for assessing risk factors, they have significant drawbacks, as they are based on the subjective adoption of evaluative decisions, which could not but affect their reliability.

Research methodology. To eliminate these shortcomings and expand the possibility of the method in the direction of improving efficiency, reliability and, most importantly, objectivity, it is proposed to use the results of physical or mathematical modeling in assessing the risk level. The type of modeling is determined by the scope of the problem to be solved and the source data. In this regard, to rank sections of the metro route by the degree of problems, a complex method is proposed that combines the capabilities of expert assessment of risk factors and the results of mathematical modeling using numerical methods.

As an expert component of the complex method, one of the expert evaluation methods of risk factors and their levels in the construction and operation of oil trunk pipelines was chosen [11]. The method is aimed at assessing a wide range of risk factors, regardless of their origin, including difficult to predict events [12]. To do this, there were applied an approach that can be described as a "clean sheet", i.e. without using any known methods or existing "from scratch" approaches.

At the same time, the focus of the analysis is aimed at assessing the initiating events (risks) that are not directly manageable during the operation of pipelines.

Some of the analysis principles used as an expert component for assessing risk factors in relation to metro operating conditions were replaced, and the method itself was improved.
First of all, the introduction of the equivalence principle - dividing the metro route when ranking into sections of the same length. The exception is the territory of stations, estimated by the sections in which it is entered. This greatly simplifies the ranking process, since the principle allows one to use only one characteristic (in our terminology, the criterion) - the total score of all the risk factors of the site.

Ranking a section of metro route by the degree of problem in accordance with the proposed method is conceptually based on the following basic principles:

- a group of experts of different levels of competence and knowledge of the specifics of metro design, construction and operation is involved in the analysis of risk factors;

- analysis of the metro route state is carried out by the most significant risk factors established from the factors presented by the expert Commission members by the total points and the selected value of the selection criteria, by assigning conditional points based on an independent expert opinion on a tenpoint scale;

- the equivalence principle - the division of subway line in the ranking;

- the principle of individuality - the most significant risk factors are set for each metro individually;

- the principle of adding risk factors through conditional points. The criterion is the sum of points (average values) of the site's risk factor levels;

- ranking of sites by the degree of problems in accordance with three levels of risk: low, medium, and high;

- the worst-case scenario, i. e., a scenario in which some sections of the same risk level, which have a total score significantly higher than the average one for their level, can be assigned a higher risk level by an expert decision.

As an example of practical implementation of the possibility and fairness of the principles laid down, the complex method was used in solving the problems of ranking the route of the Almaty metro.

From the compiled list of risk factors, the expert commission determines the most significant ones. For this, each expert, in accordance with the Delphi principle, independently evaluates the level of risk factors for the list on a 10-point scale. The most significant risk factor is risk with an average assessment score of an expert commission of at least five.

At the first stage, based on a retrospective causal analysis of the occurrence and development of risk situations and accidents that have occurred over the past five years in the world practice of construction and operation of underground metro lines, based on materials available in the open press, the expert Commission assesses all possible risk factors in relation to the Almaty metro.

The risk factor associated with changes in the stress-strain state (SSS) of the rock (ground) mass containing the section of the route is added to the most significant ones.

As an example of modeling, the territory of the "Dostyk" station of the Almaty metro was selected.

The simulation is carried out by the finite element method (FEM) [13], which is widely used in engineering design practice under complex mining and geological conditions [14]. The finite element method allows considering stresses and displacements in heterogeneous media, to study the interaction of the supports with the surrounding mountain massif, taking into account the real shape of the studied area and the deformation parameters of the supports and the massif. A rock mass containing a fixed or loose production, in turn, can have sections with different stiffness associated with the features of its structure and heterogeneity of the composition of rocks. The Initial data for modeling are the geometric dimensions of the underground structure (Fig. 1) and the physical and mechanical properties of the soil on the construction site. At the same time, the strength properties of the soil mass are the most influential factors determining the development of displacements in the cavity. Traditionally, characteristics such as grip, 


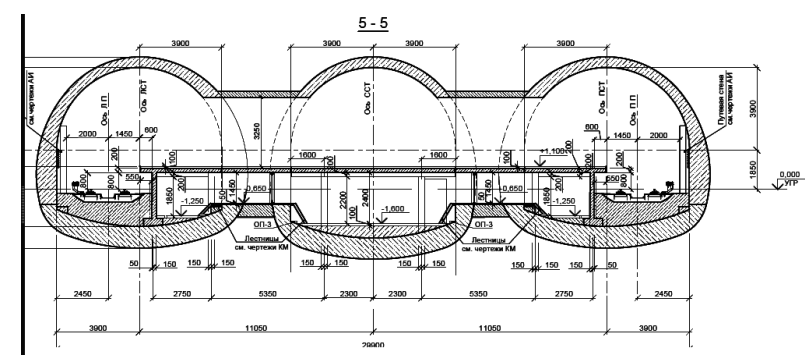

Fig. 1. Layout and dimensions of tunnels

internal friction angle, tensile and compressive strength are determined by testing soil samples in laboratories. However, the strength of a real array differs from the strength of laboratory samples. This fact is stated by various rating classifications of the rock mass [15], which take into account the presence of joints in the array, their intensity, the quality of the crack surface, and water content. The use of these classifications is an integral part of the expert assessment.

Modeling the state of the array around the metro station is performed using the PHASE2 license program of Rocscience. The calculation scheme of the problem and the finite element grid of the area are shown in Fig. 2. Soil properties are given in the Table 1.

Result of calculation. The most informative characteristics of the stress-strain state of the array are the principal stresses, as well as the movement of the development contour. The distribution of the major principal stresses (Fig. 3) is typical for an extended cavity. There is a drop in stress above and below the cavity (blue color scheme) and a concentration of stress in the sides of the extreme tunnels (yellow-green color scheme).

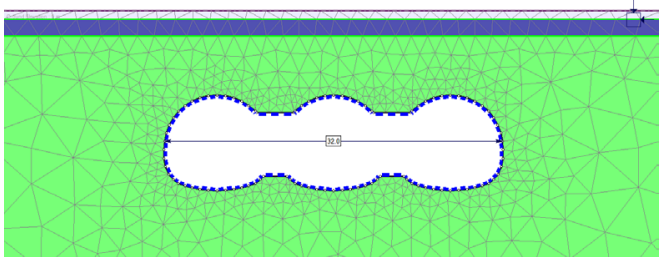

Fig. 2. Calculation scheme and finite element grid of the area

Table 1

Soil properties

\begin{tabular}{|c|c|c|c|c|c|c|}
\hline Material & $\frac{5}{0}$ & 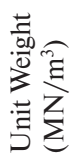 & $\begin{array}{l}\text { Young`s } \\
\text { Modulus } \\
\text { (MPa) }\end{array}$ & 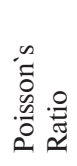 & 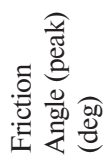 & $\begin{array}{c}\text { Cohesion } \\
\text { (peak) } \\
\text { (MPa) }\end{array}$ \\
\hline Sandy loam & & 0.017 & 18 & 0.3 & 22 & 0.036 \\
\hline Loam & & 0.017 & 14 & 0.35 & 24 & 0.035 \\
\hline Pebbles soil & & 0.021 & 68 & 0.27 & 35 & 0.034 \\
\hline
\end{tabular}

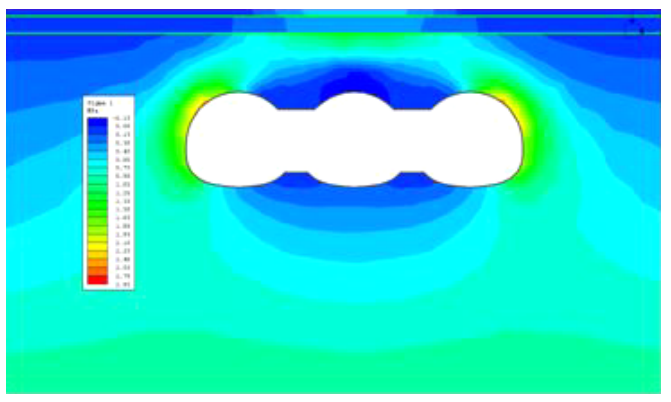

Fig. 3. Distribution of the major principal stresses
The redistribution of stresses in the soil mass determines the development of displacements in the cavity. The greatest displacements develop in the central tunnel. Such a cavity is unstable, and in fact, the soil will collapse into the worked out space. In this case, subsidence of the earth's surface will occur.

Therefore, the technology of building metro stations provides for the first side tunnels with a gap of 50-60 $\mathrm{m}$ from each other, and then the middle tunnel. The middle station tunnel passes with the adoption of the necessary measures to prevent deformation of the lining of the side tunnels. To do this, steel racks of metal pipes are installed in the side tunnels.

Using the PHASE program, the support made of reinforced concrete blocks with a thickness of $250 \mathrm{~mm}$ was modeled. A contact problem is solved that implements the interaction of the soil mass with the reinforced concrete lining [16].

Creating an appropriate rebound compensates for ground displacement (Fig. 4) up to $0.3-0.4 \mathrm{~cm}$ in the roof. The most intense deformations should be expected in the Central part. Moreover, when constructing a rigid lining, the maximum displacement is moved to the floor of the workings. In general, the construction of a rigid support in full contact with the ground mass provides a stable state of the object under study.

The highest values of displacement are possible in the soil of the average tunnel-1.7 cm. Stabilization of deformations can be carried out by constructing the "reverse arch" type structure or by additional injection of cementing solution.

The characteristics of the stress-strain state of the object changes when the mining and geological conditions on the sections of the metro route change (increase in the depth of tunneling and laying stations, change of lithology, increase in water flows). Modeling of a new geomechanical situation will give experts objective quantitative information about possible risks associated with the development of deformation processes in the vicinity of an underground structure [17].

Before ranking, experts independently assess the most significant risk factors of each site in conditional points and the results are entered in the table. An example of expert evaluation of a fragment of the Almaty metro route from 1 to $10 \mathrm{sec}-$ tions is shown in Table 2.

In accordance with the principle of adding risk factors through conditional points, the criterion is the sum of points (average points) of the expert assessment of risk factors, determined as follows.

The total score of the expert assessment of the risk factors of the $R_{k}$ section is equal to

$$
R_{k}=\sum_{i=1}^{m} \sum_{j=1}^{n} R_{i j k} .
$$

Accordingly, the sum of average points $\bar{R}_{k}$, by definition

$$
\bar{R}_{k}=\frac{1}{n} \sum_{i=1}^{m} \sum_{j=1}^{n} R_{i j k},
$$

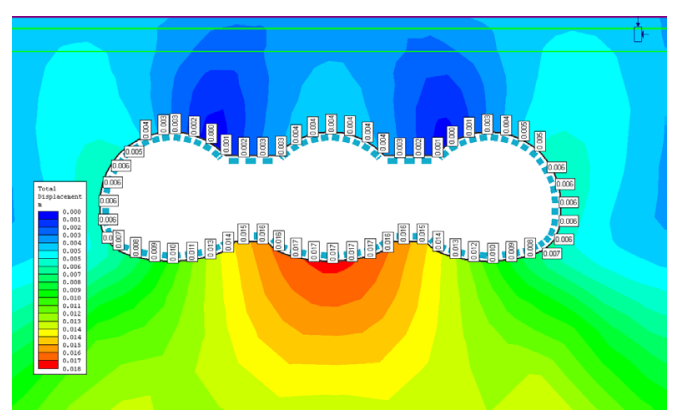

Fig. 4. Displacement contour of the cavity during installation of permanent support 
Risk factors and assessment of their level in sections $1-10$ of the metro line

\begin{tabular}{|c|c|c|c|c|c|c|c|c|c|c|c|}
\hline \multirow{2}{*}{\multicolumn{2}{|c|}{ Risk factors }} & \multicolumn{10}{|c|}{ Sections } \\
\hline & & 1 & 2 & 3 & 4 & 5 & 6 & 7 & 8 & 9 & 10 \\
\hline \multicolumn{2}{|c|}{$\begin{array}{l}\text { 1. Influence of the geological structure and physical and } \\
\text { mechanical properties of rocks and soils }\end{array}$} & 4 & 4 & 2 & 2 & 2 & 2 & 4 & 4 & 3 & 2 \\
\hline \multicolumn{2}{|c|}{ 2. Operational risks } & 2 & 2 & 2 & 2 & 2 & 2 & 2 & 2 & 2 & 2 \\
\hline \multicolumn{2}{|c|}{ 3. Manifestations of mountain pressure } & 2 & 2 & 2 & 2 & 2 & 2 & 4 & 4 & 2 & 2 \\
\hline \multicolumn{2}{|c|}{ 4. Intersection and proximity to transport links } & 2 & 2 & 2 & 2 & 2 & 2 & 2 & 2 & 2 & 2 \\
\hline \multicolumn{2}{|c|}{ 5. The load from the surface of buildings and structures } & 2 & 2 & 3 & 3 & 3 & 3 & 3 & 3 & 3 & 3 \\
\hline \multicolumn{2}{|c|}{ 6. Seismic hazard } & 2 & 2 & 2 & 2 & 2 & 2 & 4 & 4 & 2 & 2 \\
\hline \multicolumn{2}{|c|}{$\begin{array}{l}\text { 7. SSS of a rock mass including a section of highway } \\
\text { (simulation results) }\end{array}$} & 5 & 5 & 4 & 4 & 4 & 4 & 5 & 5 & 4 & 4 \\
\hline \multirow[t]{2}{*}{ The total score } & average & 19 & 19 & 17 & 17 & 17 & 17 & 24 & 24 & 18 & 17 \\
\hline & total & 133 & 133 & 119 & 119 & 119 & 119 & 168 & 168 & 126 & 119 \\
\hline
\end{tabular}

where $i, j$ are ordinal numbers of the expert Commission member's risk factors respectively; $m$ is the number of the most significant risk factors; $n$ is the number of expert Commission members.

Expert assessment of risk factors in conditional points for the route of the Almaty metro was carried out by a Commission consisting of 7 people $(n=7)$. The assessment was based on seven most significant risk factors $(m=7)$. In accordance with the equivalence principle, the metro route was ranked according to 37 sections of the same length $(300 \mathrm{~m})$ with the $k$ numbering from 1 to 37 . The numerical values of the sum of points (average and total) are shown in Table 2.

In accordance with the principle of individuality of the method, the expert Commission sets the numerical value of the boundary criteria (total points).

The ranking of metro sections by the degree of problems was carried out according to the evaluation points of the expert assessment of risk factors (Table 2) by dividing them into three levels in accordance with the boundary criteria (low, elevated, and high).

As an example, Table 3 shows the results of ranking a segment of the metro route from the $1^{\text {st }}$ to the $10^{\text {th }}$ section based on a quantitative assessment of risk factors in conditional points with translation into a qualitative indicator using the "traffic light" system.

In accordance with the principle of the worst scenario, four sections of the route were changed to the hazard level sta-

Table 3

Ranking of Almaty metro sections

\begin{tabular}{|c|c|c|c|c|c|l|}
\hline \multirow{2}{*}{$\begin{array}{c}\text { Section } \\
\text { number }\end{array}$} & \multicolumn{3}{|c|}{$\begin{array}{c}\text { Number of risks by } \\
\text { level }\end{array}$} & \multicolumn{2}{c|}{$\begin{array}{c}\text { Total score of } \\
\text { risk factors }\end{array}$} & \multirow{2}{*}{$\begin{array}{l}\text { Qualitative } \\
\text { level of risk }\end{array}$} \\
\cline { 2 - 7 } & high & elevated & low & general & average & \\
\hline 1 & - & 2 & 5 & 133 & 19 & elevated \\
\hline 2 & - & 2 & 5 & 133 & 19 & elevated \\
\hline 3 & - & 1 & 6 & 119 & 17 & low \\
\hline 4 & - & 1 & 6 & 119 & 17 & low \\
\hline 5 & - & 1 & 6 & 119 & 17 & low \\
\hline 6 & - & 1 & 6 & 119 & 17 & low \\
\hline 7 & 1 & 3 & 3 & 168 & 24 & high \\
\hline 8 & 1 & 3 & 3 & 168 & 24 & high \\
\hline 9 & - & 1 & 6 & 126 & 18 & low \\
\hline 10 & - & 1 & 6 & 119 & 17 & low \\
\hline
\end{tabular}

tus by an expert decision. Sections 7 and 8 have been upgraded from elevated to high risk. Sections 1 and 2 have been upgraded from low-risk to elevated-risk.

Discussion of results. In accordance with the proposed method, two high-risk sections with a total length of $600 \mathrm{~m}$ ( $5.4 \%$ of the total length of the metro route) were identified when ranking sections of the metro route according to the degree of problems, with the recommendation to organize continuous monitoring on them. Two sections with a total length of $600 \mathrm{~m}(5.4 \%)$ are assigned to the average level by the recommendation of the increased monitoring level. 33 sections $(9.9 \mathrm{~km} 89.2 \%)$ are classified as low level ones, and regular monitoring is recommended for them. The results confirm the success of solving the problem of improving the effectiveness of monitoring the state of the metro route by a complex method, which allows focusing monitoring capabilities on the areas with a high level of risk highlighted in the ranking. This significantly increases the reliability of situational control and the reliability of the forecast of risk situations.

Conclusion. The proposed complex method for ranking metro sections by the degree of problems based on the joint use of the expert analysis and modeling of risk situations has shown the success of solving the problem of improving the effectiveness of monitoring its condition on the example of the Almaty metro and has been adopted for implementation (implementation Act No. 12/01 of 16.09.2019). At the same time, the reliability of situational control and the reliability of the forecast, as shown by the method, are significantly increased using physical and mathematical modeling. To do this, it is preferable to model all the most significant risk factors. The principles laid down in the method can be used in any underground construction, operation of ground and underground structures.

Note. This article is based on the results of research on the topic "Geoinformation system for managing technogenic risks in conditions of high agglomeration load using topographic and geodetic and aerospace methods" No. 2018/ AP05131789.

\section{References.}

1. Solodyankin, O.V., Shepel, N.M., \& Shapoval, V.H. (2018). Protection of objects from the influence of long-term dynamic loads. Naukovyi Visnyk Natsionalnoho Hirnychoho Universytetu, (3), 80-86. https://doi.org/10.29202/nvn$\mathrm{gu} / 2018-3 / 11$.

2. Pankratova, N., Gayko, G., Kravets, V., \& Savchenko, I. (2016). Problems of Megapolises Underground Space System Planning. Journal of Automation and Information Sciences, 48(4), 32-38. https://doi.org/10.1615/JAutomatInfScien.v48. i4.40. 
3. Imansakipova, B. B. (2019). Expert risk analysis of the state of sections of the main oil pipeline and their ranking by the degree of problems. Mining journal of Kazakhstan, 10(174), 37 41.

4. Spitsyn, A. A., Imansakipova, B. B., Chernov, A. V., \& Kidirbayev, B. I. (2019). Development of scientific and methodological basis for identifying weakened zones on the earth's surface of ore deposits. Mining journal of Russia, 9(2266), 6366.

5. Alidoosti, A., Yazdani, M., Fouladgar, M. M., \& Basiri, M.H. (2012). Risk assessment of critical asset using fuzzy inference system. Risk Management, 14, 77-91. http://doi. org/10.1057/rm.2011.19.

6. Han Yi Wang, \& Samuel, R. (2016). 3D Geomechanical Modeling of Salt Creep Behavior on Wellbore Casing for PreSalt Reservoirs. SPE Drilling and Completion, 31(4), 261-272. https://doi.org/10.2118/166144-PA.

7. Sadykov, B. B., Baygurin, Zh. D., Altayeva, A.A., Kozhaev, Zh. T., \& Stelling, W. (2019). New approach to zone division of surface of the deposit by the degree of sinkhole risk. Naukovyi Visnyk Natsionalnoho Hirnychoho Universytetu, (6), 31-35. https://doi.org/10.29202/nvngu/2019-6/5.

8. Strokova, L. A., \& Ermolaeva, A. V. (2016). Zoning of the territory according to the degree of danger of subsidence of the earth's surface in the design of the main gas pipeline in South Yakutia. Proceedings of Tomsk Polytechnic University. Engineering of georesources, 327(10), 59-68.

9. Haiko, H. I., Savchenko, I. O., \& Matviichuk, I. O. (2019). Development of amorphological model for territorial development of underground city space. Naukovyi Visnyk Natsionalnoho Hirnychoho Universytetu, (3), 92-98. https://doi. org/10.29202/nvngu/2019-3/14.

10. Pankratova, N. D., Savchenko, I. O., Gayko, G. I., \& Kravets, V.G. (2018). Evaluating Perspectives of Urban Underground Construction Using Modified Morphological Analysis Method. Problems of Control and Informatics, 5, 91-102. https://doi.org/10.1615/JAutomatInfScien.v50.i10.30.

11. Nedashkovskaya, N. I. (2015). Method for evaluation of the uncertainty of the paired comparisons expert judgements when calculating the decision alternatives weights. Journal of Automation and Information Sciences, 47(10), 69-82. https:// doi.org/10.1615/JAutomatInfScien.v47.i10.70.

12. Samigullin, G.H., Egorova, D.V., \& Kutukov, S.E. (2016). Risk level analysis as a method of ensuring safe operation of the linear part of main pipelines. Bulletin of young scientist UGNTU. Ufa state petroleum technical University, 4(8), 207-211.

13. Zienkiewicz, O., \& Taylor, R. (2013). The Finite Element Method for Solid and Structural Mechanics. $7^{\text {h }}$ Edition. Elsevier Butterworth-Heinemann. Retrieved from https://www. elsevier.com/books/the-finite-element-method-for-solidand-structural-mechanics/zienkiewicz/978-1-85617-634-7.

14. Babets, D., Sdvyzhkova, O., Shashenko, O., Kravchenko, K., \& Cabana, E.C. (2019). Implementation of probabilistic approach to rock mass strength estimation while excavating through fault zones. Mining of Mineral Deposits, 13(4), 72-83. https://doi.org/10.33271/mining13.04.072.

15. Babets, D. V., Sdvyzhkova, O. O., Larionov, M. H., \& Tereshchuk, R. M. (2017). Estimation of rock mass stability based on probability approach and rating systems. Naukovyi Visnyk Natsionalnoho Hirnychoho Universytetu, (2), 58-64.

16. Carranza-Torres, C., \& Diederichs, M. (2009). Mechanical analysis of circular liners with particular reference to composite supports. For example, liners consisting of shotcrete and steel sets. Tunneling and Underground Space, 24(5), 506532. https://doi.org/10.1016/j.tust.2009.02.001.

17. Małkowski, P., Ostrowski, L., \& Bachanek, P. (2017). Modelling the Small Throw Fault Effect on the Stability of a Mining Roadway and Its Verification by In Situ Investigation. Energies, 10(12), 1-21. http://doi.org/10.3390/ en10122082.

\section{Комбінований метод оцінки факторів ризику при підземному будівництві}

\author{
Б. Б. Імансакіпова ${ }^{1}$, О. О. Сдвіжкова ${ }^{2}$, \\ Ш. К. Айтказінова ${ }^{1}$, К. Ж. Ісабаєв ${ }^{3}$, Г. С. Шакієва ${ }^{1}$
}

1 - Satbayev University, м. Алмати, Республіка Казахстан, e-mail: imansakipova@mail.ru

2 - Національний технічний університет «Дніпровська політехніка», м. Дніпро, Україна, e-mail: sdvyzhkova@ gmail.com

3 - Військово-інженерний інститут радіоелектроніки і зв'язку, м. Алмати, Республіка Казахстан

Мета. Розробка комбінованого методу якісної й кількісної оцінки факторів ризику, що супроводжують будівництво та експлуатацію підземних споруд на основі експертного аналізу і математичного моделювання чисельними методами.

Методика. При створенні комплексного методу ранжирування траси підземної споруди за ступенем проблемності були використані методи експертної оцінки, статистичного аналізу й математичного моделювання, що дозволяє оцінювати стан кожної ділянки через підсумовування балів оцінки факторів ризику.

Результати. За результатами практичного застосування розробленого методу ранжирування ділянок траси Алматинского метро за ступенем проблемності метод показав свою ефективність при вирішенні завдань забезпечення безпеки будівництва та експлуатації метрополітену, що дозволило прийняти його до впровадження.

Наукова новизна. Оцінка стану ділянки траси підземної споруди за ступенем проблемності відповідно до принципу складання факторів ризику через умовні бали, що встановлюються за результатами експертного аналізу й математичного моделювання.

Практична значимість. Метод дозволяє підвищити ефективність моніторингу стану траси підземної споруди, покращує якість ситуаційного контролю, а також прогноз проявлення ризикових ситуацій та їх розвитку. Метод може бути використаний для вирішення аналогічних завдань при підземному будівництві різних об'єктів, у тому числі при розробці родовищ корисних копалин.

Ключові слова: підземне будівництво, метрополітен, фактори ризику, квартиль, метод скінчених елементів, розиоділ напружень

\section{Комбинированный метод оценки факторов риска при подземном строительстве}

\section{Б. Б. Имансакипова ${ }^{1}$, О.О. Сдвижкова ${ }^{2}$,} Ш. К. Айтказинова ${ }^{1}$, К. Ж. Исабаев ${ }^{3}$, Г. С. Шакиева

1 - Satbayev University, г. Алматы, Республика Казахстан, e-mail: imansakipova@mail.ru

2 - Национальный технический университет «Днепровская политехника», г. Днепр, Украина. e-mail: sdvyzhkova@gmail.com

3 - Военно-инженерный институт радиоэлектроники и связи, г. Алматы, Республика Казахстан

Цель. Разработка комбинированного метода качественной и количественной оценки факторов риска, сопровождающих строительство и эксплуатацию подземных сооружений на основе экспертного анализа и математического моделирования численными методами.

Методика. При создании комплексного метода ранжирования трассы подземного сооружения по степени проблемности были использованы методы экспертной оценки, статистического анализа и математического мо- 
делирования, позволяющие оценивать состояние каждого участка через суммирование баллов оценки факторов риска.

Результаты. По результатам практического применения разработанного метода для ранжирования участков трассы Алматинского метро по степени проблемности метод показал свою эффективность при решении задач обеспечения безопасности строительства и эксплуатации метрополитена и принят к внедрению.

Научная новизна. Оценка состояния участка трассы подземного сооружения по степени проблемности в соответствии с принципом сложения факторов риска через условные баллы, устанавливаемые по результатам экспертного анализа и математического моделирования.
Практическая значимость. Метод позволяет повысить эффективность мониторинга за состоянием трассы подземного сооружения, улучшает качество ситуационного контроля, а также прогноз проявления рисковых ситуаций и их развития. Метод может быть использован для решения аналогичных задач при подземном строительстве различных объектов, в том числе при разработке месторождений полезных ископаемых.

Ключевые слова: подземное строительство, метрополитен, факторы риска, квартиль, метод конечных элементов, распределение напряжений

Recommended for publication by Zh. D. Baigurin, Doctor of Technical Sciences. The manuscript was submitted 17.12.19. 